\title{
Annibale Mottana \\ The state and the future of the Earth, planetary and environmental sciences, especially in Italy
}

Received: July 2007 / Accepted: December 2007 - (C) 2008 The Authors ${ }^{\star}$

\begin{abstract}
A critical review of the health state of the Earth sciences is carried out for the world and for Italy, with special regard to both their traditional branches and those recently developed to address the preservation of the Italian environment and cultural heritage. Past and recent achievements by Lincei members who contributed to the progress of the Earth sciences vision to changing public opinion on the impact of natural and human actions on the environment are briefly discussed. The possible contribution of renovated "Rendiconti Lincei" to distributing internationally the present best achievements by Italian Earth scientists and by foreign scientists working on Italian soil is also analyzed.
\end{abstract}

Keywords Geology, Mineralogy, Palaeontology, Applied Geosciences, Cultural Heritage

Subject codes: U12007, G17002, G24009

Ernest Rutherford shall remain known forever not only for his discoveries but also for an aphorism: "Only physics is science - all else is stamp collecting". A rude statement of this sort by such a great man of science cannot be dismissed easily, and especially by those who carry out their research at the periphery of physics, or definitively outside of it. Let's first ask then, the essential ques-

^ This is a "Springer Open Choice" article. Unrestricted non-commercial use, distribution, and reproduction in any medium is permitted, provided the original author and source are credited.

A. Mottana $(\varangle)$

Dipartimento di Scienze Geologiche, Università degli Studi di Roma Tre, Largo S. Leonardo Murialdo, 1, 00146, Roma

Tel.: +3906 54888019, Fax: +390654888201

E-mail: mottana@uniroma3.it 
tion: is studying how the Earth is made and works just an extravagant waste of time? Furthermore: is what we now call the Earth sciences (a comprehensive term encompassing mineralogy, palaeontology, geology, petrology, volcanology, geochemistry etc., with their recent applications to the environment and, lately, to extra-terrestrial planets) a true science or is it not? How then, is research on the Earth felt about by colleagues equally endeavouring to develop knowledge in other fields? Finally: what position should be taken on research for the Earth sciences by an academy such as Lincei, which is a community of scholars striving to keep up with the progress of science at the top level?

Answering these questions is the object of my following thoughts, which were primed by the current attempt at re-shaping "Rendiconti Lincei" to become a modern scientific magazine reporting innovations developed by the best Italian scholars, or else related to Italy in various ways, Earth and environment being two parts of this subject that cannot be neglected.

\section{Research on the Earth is a basic human need}

The very first undertaking for any living being is knowing well its own dwelling, and this is accomplished by man studying the Earth. The earliest Lincei academy was founded (1603) with the aim of "Rerum cognitionem et sapientiam non solum acquirere, recte, pieque simul vivendo: sed et omnibus voce, et scriptis absque ullius noxa pacifice pandere" . Indeed, most investigations carried out by the first Lincei were on natural science (or rather "natural philosophy", as the name was then), especially botany and zoology; moreover, their printing enterprises were related to spreading the results of such investigations, and made use of both Latin, the international scientific language of the time, and Italian, a language already illustrious in many fields, but hardly used for science till then. At that very time, a Linceo was shaping observational methods that would remain forever in modern physics and astronomy (Galilei, 1613, 1623), and another Linceo was freeing palaeontology from the magic lore it had inherited from the Middle Ages by revealing how to distinguish fossils, which are remnants of former living beings, from inorganic concretions (Colonna, 1616). The latter innovation paved the way for one of the soundest methods used to study how the Earth evolves in time. Undeniably, the early Lincei were not only the first researchers who could look at insects and herbs using the microscope (and illustrate them in close detail with accurate, yet artistic drawings: Cesi, 1625; Stelluti \& Greuter, 1625), but they were also studying the Earth, because they searched for and described a fossil forest (Stelluti, 1637), thus setting the scene for what would later be named paleobotany, another branch of the Earth sciences.

1 Not only to acquire knowledge and science by living honestly and piously at the same time, but also to peacefully deliver [them] to men by voice and writings without damage for anyone (my translation from Lynceographum, c. 1, cf. Nicolò, 2001 p. 3). 
In the years 1875-1883, when presidents Quintino Sella and Francesco Brioschi reorganized Lincei to become the Italian National Academy and the forum for scientific achievements made in Italy, the Earth sciences were highly considered, not for nothing, but because Sella himself was a mineralogist, and Giuseppe Ponzi, his predecessor as president, a geologist. Another mineralogist, Arcangelo Scacchi, was then leading the allied, and yet competing Società Italiana delle Scienze (detta dei XL).

At that time, quite a few amongst the best Italian contributions to Earth studies were appearing in the then newly founded "Rendiconti Lincei" in Italian, and continued to be printed there afterwards, well into the 1950s. Only later, when English was decided as the international scientific language, and publishing became a global affair under the influence of statistical, allegedly quantitative evaluations, did the role of "Rendiconti" as the forum for the presentation of top Italian science decrease. Eventually, "Rendiconti" became a journal dealing with matters of local or historical interest.

Now, the reorganized "Rendiconti" set forth to mirror again the best Italian science, and aim at being the choice venue for its presentation. However, what will be the role and state for them of the Earth sciences? Will, possibly, a lasting influence of Rutherford's aphorism negatively affect the outcome? Let's look at these queries and try answering them!

\section{Carrying out research on the Earth and environment is true science}

This is my first conclusion and my firm belief. When science is defined as the study of nature "as it is, as it was, and how it works", the Earth sciences, which deal with the natural world accessible to man, are indeed true sciences: actually, a very important component of great science, which systematizes observations, facts and hypotheses gathered from all over and seeks intimate understanding of the principles of the basis of which our universe works. Moreover, in order to achieve this ultimate result, the Earth sciences make use of a variety of concepts and discoveries that were made by other fields of learning: indeed, those fields to which nobody would refuse the name of science, e.g., the atom and its structure were first conceived by researchers in physics (J. Dalton, A. Avogadro, E. Rutherford, N. Bohr), as also were natural radioactivity, detected by $\mathrm{H}$. Becquerel and worked on by the Curies, X-ray diffraction by M. von Laue and the Braggs, X-ray fluorescence by C.G. Barkla, the recoil of gamma rays by R.L. Mössbauer; etc. All these people were physicists, and yet they contributed to the Earth sciences, perhaps unwillingly or without even knowing it, and helped them to progress.

Most apparatus used in today's Earth and environment research was invented or developed by physicists and optimized only later by mineralogists and geochemists so as to cope with the needs of investigating the natural world: The X-ray diffractometer (P- and SC-XRD), the electron microscope (TEM 
and SEM), the electron microprobe (EMP) and the sensitive high resolution ion microprobe (SHRIMP) are all examples. Even theories were usually conceived by physicists and chemists, and were just somewhat modified to confront the Earth's complex situation. Thermodynamics for example, a fundamental way to address phase stability, was conceived by J.W. Gibbs, a chemist, and V.M. Goldschmidt and D.S. Korzhinskii, two geochemists, had only to adapt it to the equilibrium and disequilibrium conditions that dominate on Earth. So should Earth scientists not be rated among the greatest scientists because of this? Physics and chemistry benefit from the feedback they received and still receive from the Earth scientists, and many researchers in those fields correctly assume that carrying out research on the Earth is a specialized application of their approach to science, thus as a part of science as a whole, albeit as small a part as they may think.

\section{The Earth sciences are alive as ever}

Mineralogy, the first branch of Earth research to reach the state of comprehensive science, was continuously under pressure and for a long time, almost from its first acceding to scientific approach when it started supplying quantitative data, at the times of A.G. Werner and R.J. Haüy (ca. 1780). It was pushed by crystallography, on one side, and by petrography, in the other side (cf. Naldrett, 2001). As a matter of fact, in the long run mineralogy benefited from both, but it only just survived as a general name because increasing specialization didn't permit the same person to carry out at the same time and with the same proficiency both the study of the structure of a mineral in the lab and the study of its equilibria with other minerals oot in the field. There were such men, however, who could carry out both jobs comprehensively and quite proficiently ${ }^{2}$; they were able to keep the mineralogy shrub growing, and even flourishing, so that it could eventually spread its seeds, despite being overshadowed by the luxuriant and mighty crystallography and petrology trees.

At the present time mineralogy is under pressure from geochemistry, and yet it is alive as ever: its mission is transferring to the Earth sciences those achievements of physics (e.g., XAFS, ME, MS-NMR), the lack of which would not permit them to reach a thorough, intimate and complete understanding of mineral behaviour in its natural context. Other branches of the Earth sciences did not always pursue this trend; petrology for example for some time has restrained itself to thermodynamic calculations based on bulk data gathered from a single, albeit very efficient apparatus such as EMP, and because of this it is now increasingly challenged by geology. This is the science that studies how the various blocks forming the Earth move and grow. To reach this goal it needs accurate $P-T$ data. That is probably why geology is no longer

2 I was lucky enough to meet these people during my career. I just remember here a few who are no longer alive: H.G.F. Winkler, A.E. Ringwood, W. Schreyer and C.V. Guidotti. 
satisfied with certain $P-T$ values obtained by petrology: they cannot be validated on the field. Indeed, raw EMP data needs better elaboration to exploit fully their intrinsic wealth of information. This job is best accomplished by crystal-chemistry. Crystal-chemistry was born soon as after modern structural crystallography started producing results (cf. Evans, 1952) and from the very beginning strove to match the atom positional data to local properties. Such associated information leads to a close insight into the behaviour of the whole structure (i.e., the mineral) when it competes for stability with other minerals (or structures), thus to a better understanding of its geological significance. Crystal-chemistry, however, also enjoys an additional power: it can predict both structure and properties of a compound, thus either promoting or discouraging its synthesis for material science applications. Conversely, it can anticipate how even traces of a certain atom would affect the bulk behaviour of the system, e.g., of melting, thus giving an indication to geologists of how the activity of a volcano may develop (cf. Prewitt, 1985).

In brief: some names changed their meanings or just disappeared from the scene, but the related branches of the Earth sciences are still alive, because the goals to be reached are still there and are still the same. Indeed, there is still a great need for an approach to Earth science based on a better use of all data extracted from both rocks (the building bricks of our planet) and minerals (the grains that are the basic constituents of such bricks). As a matter of fact, in modern Earth science equally good and coherent results can be obtained by starting from both ends: from the mighty plates, on one hand, which constitute the bulk of what we see on our planet, and from the tiny minerals, on the other hand, which constitute the smallest homogeneous units from which the plates are made. Shocking evidence of this comes from recent studies on diamond formation: not only were certain diamonds determined to be almost as old $(3.5 \mathrm{Ga})$ as the oldest Earth crust itself whilst having returned to the surface fairly recently $(53 \mathrm{Ma})$, but some of them have isotopic signatures suggesting derivation from organic carbon i.e., from precursors living on the Proterozoic crust. Their carbon atoms were, possibly, in a herb on the surface of the Earth; then they moved down (i.e., the crustal slab they were on was subducted) to a very deep layer near the boundary between the Earth's mantle and core, and eventually returned to the surface because of a mighty explosion. Such diamond studies demonstrate the great potential of modern Earth sciences when branches usually working aloof unite to solve a unique problem (cf. Cartigny et al., 1998; Haggerty, 1999; Westerlund et al., 2006).

Another approach to studying the Earth which has grown rapidly and has now produced very interesting results, so as to contribute to our understanding of certain very deep inaccessible parts, is through laboratory experiments (i.e., experimental petrology, etc.). The conditions of the Earth's interior can be reproduced and studied at various levels of depth. Laboratory studies have already reproduced the $P-T$ conditions of the Earth's inner core (Mao et al., 1998 ) and are scouting for the $P-T$ conditions presumed to exist in the large 
outer planets (Duffy et al., 1994). It is no wonder that researchers involved in such pioneering studies were awarded with the most prestigious prize: the Balzan prize 2005 went to R.J. Hemley and H.-K. Mao.

Earth sciences are also deeply involved in the present controversy regarding evolution. Actually, palaeontology was one of the main supports of Darwin's theory of natural selection, and still is the bench where most improved theories of evolution are tested and validated against those calling for an "intelligent design". Finding fossils (in Colonna's meaning of the word) in very ancient rocks and tracing dispersion spreading all over the Earth, which goes hand in hand with the increasing complexity of their forms, is one of the cornerstones of the evolution theory. Other hypotheses such as creationism or catastrophism miserably sank into oblivion, or are out of present scientific understanding. Radiometric dating, introduced in 1909 by J. Joly (a geologist, not a physicist, although all radiometric methods actually rest on physical principles), created the conditions to quantify the relative ages attributed to fossiliferous strata and even to date fossil-free rocks, so as to insert them into the proper position of the stratigraphic scale. It also helped solving many controversies on the diachronism of certain fossils that would appear to converge for their evolutionary characters.

The age of the Earth's accretion is now well-constrained to be $4.56 \mathrm{Ga}$ and was established on radiometric grounds by Earth science researchers (Schoenberg et al., 2002). Before that, they had to fight against numerous faulty prejudices, and even against a great physicist W. Thompson (Lord Kelvin, 1897). He had predicted for an Earth age as low as 50 Ma i.e., younger by three orders of magnitude than the minimum time needed to explain the gradual changes observed on Earth. Kelvin arrogantly asserted that "a great reform in geologic speculation" had to be made, but only showed that even the best physicist can be grossly mistaken when addressing a complex system. Radiometric methods now work so well that when properly applied, extraterrestrial bodies can be dated by using only $\mu \mathrm{g}$-sized samples. The age of the earliest surviving Earth crust slab has also been reliably bracketed to be 4.03-3.96 Ga on the Acasta gneiss, Canada (Stern \& Bleeker, 1998). Such an age compares well with the 4.4 Ga age of detrital zircons present in the Jack Hills, Australia basement rocks (Peck et al., 2001; Wilde et al., 2001), the crystallization temperature of which could be established on the basis of the titanium content to be as low as $700^{\circ} \mathrm{C}$ (Watson \& Harrison, 2005). Thus, what we now know for sure is that in a short period around $4.35 \mathrm{Ga}$ the Earth cooled down from a rather hot sphere to settle into the same cycle of crust formation, erosion, and sedimentation that is typical of plate tectonics, and this was the pre-requisite to making our planet the homely dwelling of today's living beings.

This brings my thoughts to point out the recent, ambitious upgrading of the Earth sciences towards becoming planetary. Ever since E.F.F. Chladni (1794) first realized that meteorites arrive from outside the Earth's atmosphere, mineralogy has been involved in the study of extraterrestrial materials. This re- 
search line has been greatly incremented by the first automatic samplings from the Moon, then from other planets, and shall increase again within the next ten years, when exploration on Mars will take place. Furthermore, as already proven by the lively debates following the discovery of biological remains (possibly bacteria) in the $4.5 \mathrm{Ga}$ old meteorite of Martian origin ALH84001, found in 1984 on the Allan Hills ice field, Antarctica (McKay et al., 1996), mineralogy will have to meet and cope with a new, very important task: verifying the possible organic-inorganic interface on Mars i.e., whether life actually existed there and, if it did, under which set of conditions. Various other branches of geology are already studying the shaping and development of Martian surface features in an atmosphere consisting mostly of carbon dioxide (>95\%), but the real issue will be scouting for the causes that might have permitted life on Mars $4.5 \mathrm{Ga}$ ago. This can only be achieved by comparing terrestrial samples with Martian ones, using for these properly fossilized material i.e., material transformed into inorganic stuff (e.g., carbonate globules containing fine-grained secondary phases of single-domain magnetite and Fe-sulphides, as they were found in the ALH84001 meteorite). As a result of this research, all Earth sciences will be spurred on (for they will be under the impatient scrutiny of all human beings), and also re-vitalized, as they will have to test again and again samples collected from all over our planet surface. The worldwide rocketing of the Earth sciences after high-flying projects such as the IUMP (International Upper Mantle Project, 1962-67) were organized (and adequately funded) warrants for a new "golden age" when the Mars project will eventually come into being.

\section{Earth sciences will expand by studying the environment and cultural heritage}

The surface of the Earth is increasingly undergoing global stress that many people believe to be related to human activities. This is usually referred to as the "global climate change", which is triggered by an anomalous increase of gases such as $\mathrm{CO}_{2}$ and $\mathrm{NO}_{x}$ in the atmosphere, possibly combined with a widening of the hole in the ozone layer over Antarctica (to which man-made greenhouse gases certainly contributed, before being banned). The extent of environmental alteration to be expected from that climate change is harshly debated and possibly overestimated, but reaching consciousness that something is going on has certainly contributed to enhancing another task for the Earth sciences that had been rather neglected for a long time: monitoring the Earth's environment.

As a matter of fact, the Earth sciences are partly responsible for environmental worsening. Mining activities were necessary for the development of human welfare, but they were often carried out with complete disregard for ethics; therefore, they have created damage to the local environment. The exploitation of a mine always leaves behind unpleasant holes (especially in poor 
countries, where daily survival takes over from environmental considerations) as well as, more important and devastating, huge banks of waste and tailings. Consequences of such reckless mishandlings were and are a large contamination of soils and waters by poisonous metals, and the formation of large sedimentary deposits of composition the Earth had never known, or, if it did, had not been during the last billion years, when life spread over the planet.

The new task the Earth sciences are called for is two-fold: a) masking the damage i.e., organizing the recovery of the landscape so that it may be again as natural as possible; b) determining the extent of soil and water pollution and suggest ways to beneficiation. Both are a pre-requisite to sustainability i.e., to ensure proper life conditions to future generations, and these are global, not regional tasks.

Bringing landscape conditions back to either as close as possible to the early, natural ones or, at least, useful again to human life, is a job that geomorphology (a branch of study where geology and geography meet, with additional contributions from petrology and landscape architecture) can carry out satisfactorily, although never completely, because scars on the Earth's surface can be concealed, largely, but never entirely restored. The main problem lies in fighting unscrupulous conservation policies, often backed by politics and/or organized crime: in such cases, the scientific approach is not welcome, and the inevitable costs of restoration are labelled as unnecessary or arbitrary, mostly by the very ones who had permitted damage to take place in the first place.

Pollution of soils and water on the other hand, can be such a great problem that it involves both ethics and welfare, two major public issues that scientists operating in the Earth science field are usually unprepared to cope with. Their suggestions, based on their knowledge on how the Earth system works, is then often disregarded in favour of hastily decided palliatives, which have the advantage of decreasing public concern, but which carry with them solutions that, in many cases, make things worse. Indeed, applied Environmental science is a great opportunity for all the Earth sciences, but it is the source for them of quite a few problems too. That is why so many Earth scientists still prefer dedicating themselves to distant matters, such as studying the atmosphere of the Precambrian past or simply that of the early Quaternary: they leave the pressing problems to others, who possibly are less adequate to solve the problem, and also are often censored as "greedy", or as "speculators" of the increasing public environmental concern. There is no bright future in science for such a dull mind-set.

Another recent development for the Earth sciences is towards the preservation of Cultural Heritage. Most works of art have been made on supports or using pigments that are of natural derivation i.e., stones and minerals, and they are often exposed to the natural environment. Consequently, they are best studied using the same methods as modern mineralogy, petrology and geochemistry use, provided they are modified in such a way as not to damage the artwork. There is indeed a very large possibility for this application, which in- 
volves most modern non-pervasive methods and (not a minor additional gain!) contributes to restoring people's goodwill towards science ${ }^{3}$. Moreover, conservation implies restoration, and this in turn requires looking for and re-opening ancient mines and quarries to study better and also recover the original stones or minerals so that they may be used again to integrate the decayed parts of the artwork. Other sophisticated applications of Earth science methods to Cultural Heritage refer to studying the causes of decay (e.g., why certain dyes used in frescos change their colour or blacken with time) or to reconstructing the ancient methods to produce materials (e.g., inks, cosmetics, instruments, or the dyes themselves). A minor, but highly specialized application is in forensics i.e., contributing to detecting frauds and crimes by analyzing the records represented by minimal traces of natural pollutants.

\section{Italian Earth sciences are alive and healthy}

The Italian Earth sciences suffer a great drawback: as all the sciences in the university system, they are bureaucratized and parcelled into as many as twelve disciplinary sectors that almost never communicate. This organization weakens the overall advancement of scientific knowledge, which is based on sharing efforts to solve a problem and a common goal. Politics is usually blamed for it. However, as a matter of fact, such parcelling is not due to politicians, but it was requested by university academics (not by Academicians!) for career reasons and for easier access to funding opportunities. In the long run, it has badly damaged science, for it has induced researchers to care only for the advancing of their own field and of their personal interests, rather than of the general advancement of knowledge on the Earth system. Certainly, it does not favour a deeper study of the Earth locally i.e., in Italy, and instead produced lots of scattered, minor contributions. This is why the most important discoveries, which were made on Italian soil during the past decades and made them the reference sites for Earth scientists all over the world, are to be credited to foreign researchers: e.g., the KS vs. HKS series in Roman volcanics to Appleton (1972), the Messinian desiccation of the Mediterranean sea to Hsü and co-workers (1973), the iridium anomaly at the K-T boundary at Gola del Bottaccione near Gubbio, Umbria, to the Alvarez and their co-workers (1980), the coesite-bearing rocks at Parigi near Cuneo, Piemonte, to Chopin (1984), etc.

Notably, all those very far-reaching and inspiring discoveries were made in the 1970s and 1980s. Later on, the best advised Italian Earth scientists struggled but kept up with these new issues, most often by cooperating with the

\footnotetext{
3 Physics because of the atomic bomb (cf. Hiroshima) and of the risk inherent in nuclear power plants (e.g., Chernobyl) and nuclear waste, and chemistry because of the extensive air, soil and water pollution derived from its industries (e.g., Bhopal), are both held in check by people who claim to be environment-friendly. The Earth sciences in general are not ill considererd (or rather, to be on the safe side, not yet) apart from petroleum geology, owing to some disastrous oil spills (e.g., Exxon Valdez).
} 
same foreigners who had made such discoveries, or with other foreign scientists who has received inspiration from them. They often succeeded: Roberto Compagnoni is now the reference person for the whole Dora Maira area (e.g., Compagnoni \& Rolfo, 2003) and has driven numerous younger researchers there who are now spread over all the continents; Angelo Peccerillo has synthesized of the entire Plio-Quaternary volcanism in central Italy (Peccerillo, 2005) that is acknowledged to be the follow-up of the classical (but obsolete, by now) memoir by H.S. Washington (1906) on the leucite-bearing rocks around Rome; and, last but not least, Maria Bianca Cita Sironi (who, ahead of time in comparison to other Italian scientists, made her competence freely available to all foreign scientists coming to Italy and wishing to work here out in the field, to return home with samples to submit to their new and better facilities) is now acknowledged to be the most accomplished expert on how sedimentation developed not only on the Italian peninsula, but all over the Mediterranean Sea.

I could continue, but I refrain from doing so, and rather move to point out the most significant innovation that was conceived by Italians in Italy (despite all the difficulties due to the quivering environment they had to work in) and was well received abroad. This is the discovery of the eo-alpine orogenic phase and associated high-pressure metamorphism: Giorgio Vittorio Dal Piaz and his coworkers (Dal Piaz et al., 1972) made the discovery on mostly structural grounds in a fairly small area (Sesia zone) and yet they turned upside down most ideas about folding and development of the entire Alps. As a matter of fact, theories on the Alps were already in turmoil after the discovery of the Lepontine hightemperature static phase superimposed on a dynamo-metamorphic barrovian phase, and the time was appropriate to move ahead and away from Argand's (1911) classical model about the formation of the Alpine nappe pile to a more modern model. Not only did the Dal Piaz et al.'s (1972) paper drive top scientists to carry out studies on Italy, but it created the general conditions for a wider acceptance of the Miyashiro's "paired belts" hypothesis (1961) that fitted so well the then incoming plate tectonics. The fact that later, radiometric studies have challenged their model too is in the array of normality: when a new model arises it must be verified, and by verifying it something better and newer usually is worked out!

I stop here with past achievements, and turn to list some current results the Italians can be proud of, and in fact position Italy close to the front of today's Earth science. To start with, mineralogy is greatly valued worldwide for the discovery of ca. 90 new minerals over the past 50 years, a result making Italy the third or fourth best country for mineral hunting in the world. Among those new species, mutinaite (Galli et al., 1997) is to be pointed out. Although that mineral was found in Antarctica, the name given to it recalls the great role the Modena school has had and is still having in zeolite studies i.e., on minerals that are fundamental in many current industrial applications. Among geologically-significant mineral groups, the amphiboles, the micas, and certain 
VHP and fibrous minerals are acknowledged worldwide to be best studied in Italy. Petrology is also keeping pace, not only working on Italian soil, but all over the world, in close connection with volcanology and geothermics i.e., two branches of the Earth sciences that are sensitive to environmental matters too, including the problem of clean energy supply. Medical problems related to safety, such as cancer induced by inhalation of mineral fibres, are also studied, thus bridging the gap between Earth and Life sciences.

Structural geology is a fast-moving branch amongst those sciences related to Geology s.s. Italian structural geologists have worked extensively on the Alps, particularly after the discovery of their very recent, episodic uplift, but they also studied again and again the Apennines, particularly in their sector around the Tyrrhenian deep, where there is evidence of the orogenic development interplay with geo-morphological features, volcanological problems and incipient metamorphism. Studies based on numerical and laboratory simulations have also been done, particularly into the ways subduction and postorogenic extension develop, not only in Italy, but in many other areas of the world. Indeed, Italian structural geologists have turned international, in the sense that they not only study practically on and around all continents, but also that their results are taken into consideration and appreciated all over the world.

Knowledge on stratigraphy has been greatly upgraded by reconstructing particularly the Triassic series and, more generally, the carbonate sequences all over the Alps and the Apennines. Notably, carbonate lithofacies are now understood to be palaeolatitute indicators and are used to reconstruct the habitats of pelagic and terrestrial species, often working in conjunction with stable isotope geochemists, thus bridging the gap between two apparently fairly remote branches of the Earth sciences. Palaeontological and palaeoecological studies have been particularly intense concerning the development of the Quaternary, both in Italy e.g., at Altamura, where a complete Homo neanderthalensis has been found in situ, locked in a cave by the aragonite concretions, and abroad, namely in the Afar depression of Ethiopia, well-known to be exceptionally rich in remains of Homo and of previous genus, thus giving significant contributions to the evolution theory.

Most papers that have gained Italians internationally recognition (ca. 4\% of the top highly cited publications of the last decade have an Italian first author: cf. King, 2004) are now in English, the international language of science since World War II. As a matter of fact, the Italian Earth scientists were slow to accept this, and some stimulating papers of the 1950-70's escaped worldwide recognition only because of the language barrier. However, present-day scientists, at least regarding writing, are on top of this issue.

Italy is well known to have been a key area for the development of the Earth sciences in the past (in pioneering times when all European scientists flocked to visit Vesuvius and Aetna, or were climbing Val d'Ossola and Val Formazza to learn about the nappes, or scrambling through Tuscany and Liguria for 
ophiolites). This is so also today: innovative experiments have been done such as those aiming to moderate the Aetna lava flows (Barberi et al., 1993), or at stabilizing the Leaning tower of Pisa (Rampello and Callisto, 1998; cf. Settis et al., 2005), or at repositioning Cimabue's shattered frescos on the ceiling of the Assisi upper basilica after the 1997 earthquake. They attract not only interested visitors, but also scientists, eager to learn methods considered best for the preservation of the Environment and of Cultural Heritage. Indeed, there is no doubt that Italy has taken world leadership of such a side-branch of the Earth sciences. Mineralogy and petrology, particularly, apply their methods to scientifically studying all works of art from prehistoric to recent, following ideas that were set forth by Cesare Brandi in the early 1950s and constitute now the scientific basis of conservation. A final, very good example is the restoration of the Last Supper by Michelangelo, which required studying not only lapis lazuli and azurite (the costly minerals used for blue), but also the earths used for umbers, as well as the humble stones and the mortar used for the huge wall of the Sistine Chapel.

The overall Italian Earth science community had two recent possibilities to expose itself to international scrutiny: the International Mineralogical Association $16^{\text {th }}$ general assembly in Pisa (1994) and the $32^{\text {nd }}$ International Geological Congress in Florence (2004). At both meetings the Italians did well, not only scientifically, but also from the point of view of organization: a result that surprised most foreign participants, or at least those used to considering Italy the country of mandolin-players, not of scientists able to use an ion microprobe just as well as their sledge-hammer!

\section{Conclusions and inferences: the future role of Earth sciences in "Rendiconti Lincei"}

All Earth sciences underwent a great shock between the years 1965 and 1968, when the paradigm of global tectonics, with its mobile lithospheric plates drifting over a soft upper mantle, succeeded in definitively overthrowing the previous paradigm of an essentially static crust, just moving up and down and at times folding along certain lines. Structural geology was certainly the first branch of the Earth sciences to be affected by that paradigmatic change, but all other more distant branches inevitably followed, sooner or later: even crystallography, when it was discovered that tiny crystals on which it works could be more proficiently studied when taken to special sites, where specific geologically-controlled chemical and physical equilibration conditions are met, rather than at random from mines, outcrops or museums. Indeed, increased consciousness of geologically referenced data was the main reason why crystal-chemistry blossomed and started contributing strongly to knowledge of the Earth. 
As a general outcome of the paradigm change, all rejuvenated Earth sciences, trusting the new concepts and supported by new experimental methods (derived from physics!), took off to re-explore and re-interpret our planet, and also took upon themselves to study extraterrestrial samples and evidence provided by manned and unmanned missions. That impetuous forward push not only produced myriads of new data (and quite a few errors), but it opened new, till that moment never applied ways to exploit the Earth's resources, consequently increasing damage to the Environment to an unprecedented extent.

Restoring the Environment, and also predicting what is going to happen on Earth if the current increasing trend of atmospheric pollution continues, is the present duty of the Earth sciences as a whole. Such forecasting is a very difficult task indeed, because it would only be valid if no human intervention with respect to boundary conditions would occur. The Earth sciences should remain on their traditional track: investigating the natural world without trying to bend nature to their own models. There is their chance to show their worth, and this opportunity is equally offered to mature branches such as mineralogy, stratigraphy, etc., and to other new disciplines, which have been rapidly upgraded to become the leading Earth sciences of the future. Glaciology, for instance, which did not even exist in 1830 and lagged behind for a long time because of its close ties with geography (or with geodesy, a branch of applied mathematics that has almost nothing in common with the Earth sciences), is now a science at the top of general interest, since it has been able to make judicious use of a number of techniques, methods and concepts developed by other branches of the Earth sciences (and even by other sciences) and gather there from novel, intriguing results. This new glaciology, under the pressure of the climate debate, is now much better linked to the Earth sciences. Indeed, it has by now attained a reasonably clear picture of eight thermal regime changes which occurred on Earth in the past (up to 740,000 years in the $3270 \mathrm{~m}$ long drill-hole at Dome C, Antarctica; cf. Augustin et al., 2004), thus it is also able to forecast on sound scientific grounds what global climate change will be for the next 10,000 years at least: "Given the similarities between this earlier warm period [i.e., the interglacial following Termination V] and today, our results may imply that without human intervention, a climate similar to the present one would extend well into the future" (Augustin et al., 2004). As always in science, such a forecast is now submitted to validation, but the first checks appear to support it entirely, in spite of certain pessimistic models, which would argue for melting of the Greenland ice cover resulting in a rise in sea level and the flooding of coastal plains where millions live at present and widespread testimonies of past civilizations are found.

At the opposite end of the size scale, mineral nanoparticles i.e., those little crystals that range in length from a few to some tens of nanometers, are under increasing study by crystal-chemistry and physics, because they are expected to vary their physical properties by deviating from the behaviour of the equivalent bulk phases. Such changes may be in the electronic structure (even for 
insulators which most minerals are), in the surface free energy, in the surface site distribution and both in the internal and surface atomic structures, etc. All changes influence surface redox processes, thus they may have changed the local geological regime too, in an as yet unpredictable way (Hochella, 2002). Furthermore, there is consensus that life on Earth was first made possible by the aggregation of mineral nanoparticles under special, anoxic conditions. This model requires verification by all possible means before being validated, and there is also a great need to study how mineral particles behave when sited in organic tissues: actually, this type of investigation is already under way because of its biotechnological implications.

Earth sciences are alive and healthy, but they suffer from the typical disease related to being young (again): they grow too fast to properly evaluate their own results, and consequently sometimes take the wrong paths. This happens all over the world and in Italy too, although less in Italy than elsewhere, because the chronic lack of funds here compel the Earth scientists to be cautious and to plan studies less hastily than is being done in other countries. The existence in Italy of a public board boasting the name "Ministero dell'Ambiente" is of no use to Earth science research, because most funds available are allocated to preservation organizations, which are so poorly endowed with scientific ideas that they are unable even to understand that nothing can be done about the incoming global climate change. Whatever preservation means are applied, animals will move away and trees will shift their habitat. Thus the environment of Italy will change completely, but only superficially: the landscape will remain, although it will not be exactly the same because its degradation regime will change somewhat too. The solid backbone of Italy will remain intact for a long time: indeed, the rocks and minerals that constitute the basement of the peninsula will require hundreds of years to sink under the uprising ocean water, and millions of years to move away on the plates carrying them. "Rendiconti Lincei", a rejuvenated journal which aims to show the best of Italian science in the current international language and according to well-organized publication methods, certainly will not gain from such a petty, politically-driven management of public funds, as Lincei Academy itself never benefited from them, not even to support its managing "Giornata dell'Ambiente", although Italy as a country is committed to organizing this every year. However, to gain deeper insight, the Ministry's narrow-minded funding policy plays in favour of the Academy and its independency, because it has freed it from the constraints politicians usually impose on the agencies they finance, and has given it full freedom to allow to valuable scientists only to be heard.

The same freedom will characterize the future "Rendiconti": the Editorial Committees will be able to select manuscripts using as a touchstone only scientific quality, in an attempt to offer to worldwide readers a picture of the Italian Earth science as updated and dignified as possible. If there are errors, they will certainly be minor. By contrast, all innovations will certainly find in the new "Rendiconti" a quick, reliable, well considered means of circulation. 
Thus, not only will they be rapidly and efficiently presented, but also, hopefully, they will be positively acknowledged by the international community of scientists. The immediate problem, for "Rendiconti", is to make Italian scientists understood now that they have a new powerful tool available to distribute the results of their studies. This is, indeed, a problem common to all Italian science, not only to Earth scientists: it took years for Italians to get used to exposing their studies to peer-review and to offering them for publication in international journals; it may take years again to change their habits and to publish work in the renovated "Rendiconti", where peer-review will also be done and handled according to stiff international standards!

Acknowledgements. S. Pignatti, F.P. Sassi, F. Seifert, G. Orombelli and S. Merlino read this manuscript at various stages of preparation and volunteered useful advice.

\section{References}

1. Alvarez LW, Alvarez W, Asaro F, Michel HV (1980) Extraterrestrial cause for the Cretaceous-Tertiary extinction. Science 208: 1095-1108

2. Appleton JD (1972) Petrogenesis of potassium rich lavas from the Roccamonfina volcano, Roman Comagmatic Region. Journal of Petrology 13: 425-456

3. Argand E (1911) Les nappes de recouvrement des Alpes Pennines et leur prolongement structuraux. Matériaux pour la carte géologique de la Suisse, N.S. 31

4. Augustin L, Barbante C, Barnes PR, Barnola JM, Bigler M, Castellano E, Cattani O, Chappellaz J, Dahl-Jensen D, Delmonte B et al. (2004) EPICA community members. Eight glacial cycles from an Antarctic ice core. Nature 429: 623-628

5. Barberi F, Carapezza ML, Valenza M, Villari L (1993) The control of lava flow during the 1991-1992 eruption of Mt. Etna. Journal of volcanology and geothermal research 56: 1-34

6. Cartigny P, Harris JW, Javoy M (1998) Eclogitic diamond formation at Jwaneng: No room for a recycled component. Science 280: 1421-1424

7. Cesi F (1625) Apiarium Ex frontispiciis naturalis theatri Principis Federici Caesii Lyncei S. Angeli et S. Poli Princ. I. March. M. Caelii II. etc. Baron. Rom. depromptum quo universa mellificum familia ab suis prae-generibus derivata in suas species, ac differentias distributa in physicum conspectum adducitur. Romae, ex typographeio Iacobi Mascardi

8. Chladni EFF (1794) Über den Ursprung der von Pallas gefundenen und anderer ihr ähnlicher Eisenmassen und über einige damit in Verbindung stehende Naturerscheinungen. Riga, Hartknoch

9. Chopin C (1984) Coesite and pure pyrope in high-grade blueschists of the western Alps: A first record and some consequences. Contributions to Mineralogy and Petrology 86: $107-118$

10. Colonna F (1616) Fabii Columnae Lyncei De glossopetris dissertatio. In: Fabii Columnae Lyncei minus cognitarum stirpium Pars Altera in qua non tam novae plures plantae eaeq. rariores a nemine hactenus, aut animadvesae aut descriptae nunc primum proponuntur, quam nonnullae aliae apud antiquos dubiae, atq. obscurae dilucidantur. Ad Ill. ${ }^{\mathrm{mum}}$ et Rever. ${ }^{\text {mum }}$ Principem ac Dominum Odoardum Farnesium S.R.E. Cardinalem Amplissimum. Cum imaginibus ex typis aeneis, elencho rerum initio, et indice in fine locupletissimo. Fabii Columnae Lyncei Purpura. Hoc est de purpura ab animali testaceo fusa, de hoc ipso animali aliisque rarioribus testaceis quibusdam. Romae, apud Iacobum Moscardum, 31-39

11. Compagnoni R, Rolfo F (2003) UHPM units in the western Alps. In: Carswell DA, Compagnoni R (eds) Ultrahigh Pressure Metamorphism. EMU Notes in Mineralogy 5: 13-50 
12. Dal Piaz GV, Hunziker J, Martinotti G (1972) La zona Sesia-Lanzo e l'evoluzione tettonicometamorfica delle Alpi nord-occidentali interne. Memorie della Società Geologica Italiana 11: 433-460

13. Duffy TS, Vos WL, Zha C-S, Hemley RJ, Mao H-K (1994) Sound velocities in dense hydrogen and the interior of Jupiter, Science 263: 1590-1593

14. Evans RC (1952) An introduction to crystal chemistry. Cambridge, Cambridge University Press

15. Galilei G (1613) Istoria e Dimostrazioni intorno alle Macchie Solari e loro accidenti comprese in tre lettere scritte all'Illustrissimo Signor Marco Velseri Linceo Duumviro d'Augusta Consigliero di Sua Maesta Cesarea dal Signor Galileo Galilei Linceo Nobil Fiorentino, Filosofo, e Matematico Primario del Sereniss. D. Cosimo II. Gran Duca di Toscana. Si aggiungono nel fine le Lettere, e Diquisizioni del finto Apelle. Roma, appresso Giacomo Moscardi

16. Galilei G (1623) Il Saggiatore, nel quale con bilancia esquisita e giusta si ponderano le cose contenute nella Libra Astronomica e Filosofica di Lotario Sarsi Sigensano. Scritto in forma di lettera all'Ill.mo e Rever.mo Mons.re D. Virginio Cesarini $\mathrm{Acc}^{\mathrm{O}}$ Linceo $\mathrm{M}^{\mathrm{O}}$ di Camera di N.S. dal Sig ${ }^{\mathrm{e}}$ Galileo Galilei Acc ${ }^{\mathrm{O}}$. Linceo, Nobile Fiorentino, Filosofo e Matematico Primario del Ser. ${ }^{\text {mo }}$ Gran Duca di Toscana. Roma, appresso Giacomo Mascardi

17. Galli E, Vezzalini G, Quartieri S, Alberti A, Franzini M (1997) Mutinaite, a new zeolite from Antarctica: The natural counterpart of ZSM-5. Zeolites 19: 318-322

18. Gottardi G, Galli E (1985) Natural zeolites. Berlin: Springer-Verlag

19. Haggerty SE (1999) A Diamond trilogy: Superplumes, Supercontinents, and Supernovae. Science 285: 851-860

20. Hochella MF (2002) Nanoscience and technology: The next revolution in the Earth sciences. Earth and Planetary Science Letters 203: 593-605

21. Hsü KJ, Ryan WBF, Cita MB (1973) Late Miocene desiccation of the Mediterranean. Nature 242: 240-244

22. Joly J (1909) Radioactivity and Geology. London, Constable

23. King DA (2004) The scientific impact of nations. Nature 430: 311-316

24. Mao H-K, Shu J, Shen G, Hemley RJ, Li B, Singh AK (1998). Elasticity and rheology of iron above $220 \mathrm{GPa}$ and the nature of the Earth's inner core. Nature 396: 741-743

25. McKay DS, Gibson EK Jr., Thomas-Keprta KL, Vali H, Romanek CS, Clemett SJ, Chillier XDF, Maechling CR, Zare RN (1996) Search for past life on Mars: Possible relic biogenic activity in Martian meteorite ALH84001. Science 273: 924-930

26. Miyashiro A. (1961) Evolution of metamorphic belts. Journal of Petrology 2: 277-311

27. Naldrett AJ (2000) Mineralogy is alive! European Jounal of Mineralogy 12: 5-6

28. Nicolò A (ed) (2001) Lynceographum quo norma studiosae vitae Lynceorum philosophorum exponitur. Accademia Nazionale dei Lincei, Roma, xv, 218

29. Peccerillo A (2005) Plio-Quaternary volcanism in Italy: Petrology, geochemistry, geodynamics. Berlin: Springer-Verlag

30. Peck WH, Valley JW, Wilde SA, Graham CM (2001) Oxygen isotope ratios and rare earth elements in 3.3 to $4.4 \mathrm{Ga}$ zircons: Ion microprobe evidence for high $\delta^{18} \mathrm{O}$ continental crust and oceans in the Early Archaean. Geochimica et Cosmochimica Acta 65: 4215-4229

31. Prewitt CT (1985) Crystal chemistry: past, present, and future. American Mineralogist 70: 443-454

32. Rampello S, Callisto L (1998) A study on the subsoil of the Tower of Pisa based on results from standard and high-quality samples. Canadian Geotechnical Journal 35: 1074-1092

33. Schoenberg R, Kamber BS, Collerson KD, Eugster O (2002) New W-isotope evidence for rapid terrestrial accretion and very early core formation. Geochimica et Cosmochimica Acta, 66: 3151-3160 
34. Settis S, D'Elia M, Jamiolkowski M et al. (2005) La torre restituita. Gli studi e gli interventi che hanno consentito la stabilizzazione della torre di Pisa (4 voll.). Roma, Ministero per I Beni e le Attività Culturali. Bollettino d'Arte. Volume speciale 2005

35. Stelluti F, Greuter M (1625) Urbano VIII Pont. Opt. Max. Cùm accuratior ME $\Lambda$ I $\Sigma \Sigma$ ОГРАФІА, à Lynceorum Academia, in perpetuae devotionis Symbolum ipsi offeretur. Franciscus Stellutus Lynceus Fabr. ${ }^{\text {is }}$ microscopio observabat. M. Greuter delineabat incidebat. Romae, [Mascardi]

36. Stelluti F (1637) Trattato del legno fossile minerale nuovamente scoperto nel quale brevemente si accenna la varia, \& mutabil natura di detto Legno, rappresentatovi con alcune figure, che mostrano il luogo dove nasce, la diversità dell'onde, che in esso si vedono, e le sue così varie, e meravigliose forme. Di Francesco Stelluti Accad. Linceo da Fabriano. All'Emin. ${ }^{\text {mo }} \&$ Rever. ${ }^{\text {mo }}$ Sig. Card. Francesco Barberino. Roma, appresso Vitale Mascardi

37. Stern RA, Bleeker W (1998) Age of the world's oldest rocks redefined using Canada's SHRIMP: The Acasta gneiss complex, Northwest Territories, Canada. Geosciences in Canada 25: 27-31

38. Thompson W (Lord Kelvin) (1897) The age of the Earth as an abode fitted for life. Annual Report of the Smithsonian Institution 337-351

39. Washington HS (1906) The Roman Comagmatic Region. Washington, Carnegie Institution of Washington 57

40. Watson EB, Harrison TM (2005) Zircon thermometer reveals minimum melting conditions on earliest Earth. Science 308: 841-844

41. Westerlund KJ, Shirey SB, Richardson SH, Carlson RW, Gurney JJ, Harris JW (2006) A subduction wedge origin for Paleoarchean peridotitic diamonds and harzburgites from the Panda kimberlite, Slave craton: Evidence from Re-Os isotope systematics. Contributions to Mineralogy and Petrology 152: 275-294

42. Wilde SA, Valley JW, Peck WH, Graham CM (2001) Evidence from detrital zircons for the existence of continental crust and oceans on the Earth 4.4 Gyr ago. Nature 409: 175-178 